\title{
الوعي الديني وأثره الفقهي والاعتقادي لمواجهة الوباء (جائحة كورونا أنموذجاً) دراسة تطبيقية على شريحة من المجتمع السعودي
}

The impact of religious awareness, Jurisprudence and belief to confront the epidemic (Corona pandemic as a model) an applied study on a segment of

\section{Saudi society.}

\section{الدكتورة/ أحلام محمد عقيل}

أستاذ مساعد، قسم الدر اسات الإنسانية، كلية العلوم الأساسية، جامعة الملك سعود للعلوم الصحية، المملكة

$$
\text { العربية السعودية }
$$

Email: $\underline{\text { Ahlamakeel3@gmail.com }}$

$$
\text { ملخص البحث: }
$$

تعتبر جائحة فايروس كورونا حدث معاصر وهام لتفعيل الوعي بالأحكام الثر عية لمواجهة الوباء وتقييم نقاط الضعف والقوة، ومتابعة أثر ذلك على الفرد و المجتمع، وتهدف هذه الدر اسة إلى معرفة مدى الوعي الديني في الأصول الفقهية والاعتقادية المتعلقة بالوباء ومعرفة مدى أثر ذلك الوعي في مواجهة الوباء و الحظر الكامل أو الجزئي، واستخدت الباحثة المنهج الوصفي المسحي ليشتمل على عينة أكبر بهدف وصف الظاهرة المدروسة من حيث طبيعتهاودرجة وجودها فقط، دون أن يتجاوز ذلك إلى در اسة العلاقة أو استتناج الأسباب، و المختار هو عينة عشوائية تثمل الثباب و الكبار، والنساء والرجال، بمختلف الطبقات المعيثية والتعليمية

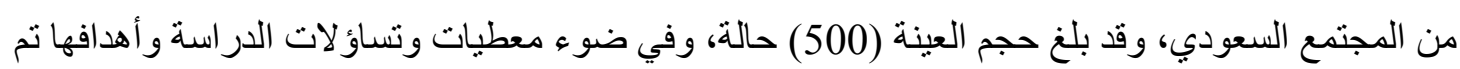
بناء الأداة (الاستبانة)، وتكونت في صورتها النهائية من ثلاثة أجزاء: المقدمة و التعريف بأهداف الدراسة، و البيانات الأولية الخاصة بأفراد عينة الدراسة، ومن نََّّ الأسئلة المتعلقة بمحاور الدراسة الدة. استخدمت الباحثة المعالجات الإحصائية (SPSS)، وبعد ذلك تم حساب المقاييس الإحصائية: التكرارات، و النسب المئوية؛ للتعرف على خصائص أفراد الدراسة، وتحديد استجاباتهم تجاه عبار ات المحاور الرئيسة التي تتضمنها أداة الدر اسة، وتوصلت الدر اسة إلى ارتفاع في نسب الوعي الديني العام لما فوق المتوسط، و العلم بالمسائل الفقهية

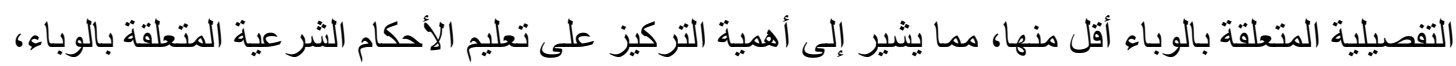

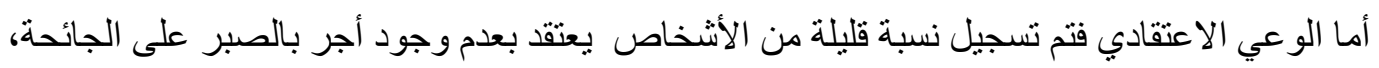




$$
\text { المجلة الدولية لنشر البحوث والدراسات }
$$

International Journal of Research and Studies Publishing

ISSN: 2709-7064
المجلد الثالث - الإصدار الرابع والعشرون تأريخ الإصدار: 20 أكتوبر 2021م المدار الع والعشر

و أنه مجرد حدث كوني و لا علاقة لله به، ومع كون النسبة قلبلة أقل من 10\% إلا أن ذلك يعتبر قدحا صريحا

في جناب الاعتقاد وينبغي عدم تجاهله في التعليم الثرعي، وتضمنت النتائج آثار ا متعددة يمكن الاطلاع عليها

في الدر اسة و التوصيات بشأنها.

كلمات مفتاحية: الوعي الديني، مواجهة كورونا شرعيا، آثار كورونا.

The impact of religious awareness, Jurisprudence and belief to confront the epidemic (Corona pandemic as a model) an applied study on a segment of Saudi society.

\begin{abstract}
Dr/ Ahlam Mohammad Akeel
Assistant Professor, Department of Human Studies, College of Basic Sciences, King Saud University for Health Sciences, Saudi Arabia
\end{abstract}

\title{
Abstract:
}

The Corona Virus pandemic is a contemporary and important event to activate awareness of the legal rulings to confront the epidemic and assess weaknesses and strengths, and follow up on its impact on the individual and society. This study aims to know the extent of religious awareness in the jurisprudence and belief principles related to the epidemic and to know the extent of the impact of that awareness in confronting the epidemic, either in complete or partial ban. The researcher used the descriptive survey method to include a larger sample in order to describe the studied phenomenon in terms of its nature and degree of existence only, without going beyond the relationship or deduce the reasons, and the chosen is a random sample that includes young people, adults, women and men in various living and educational classes of the Saudi society. Its final image has three parts: Introduction and definition of the objectives of the study, and the initial data of the study sample members, and then questions related to the axes of the study. The researcher used the statistical treatments (SPSS), 
after which the statistical measures were calculated: frequencies, percentages; To identify the characteristics of the study members, and to determine their responses to the statements of the main axes included in the study tool, the study found a rise in the rates of general religious awareness, and knowledge of detailed jurisprudential issues related to the epidemic is less than the general awareness, which indicates the importance of focusing on teaching the rulings related to the epidemic. As for the belief awareness, a small percentage of people were recorded who believe that there is no reward for patience during the pandemic, and that it is just a cosmic event and has nothing to do with Allah, Although the percentage is few, less than $10 \%$, it is still considered a blatant sin of belief and should not be ignored in legal education. The results included multiple effects that can be viewed in the study and the recommendations thereon.

Keywords: religious awareness, confronting Corona legally, the effects of Corona.

$$
\text { الحمد لله و الصلاة و السلام على سيدنا محمد و على آله وصحبه أجمعين. }
$$

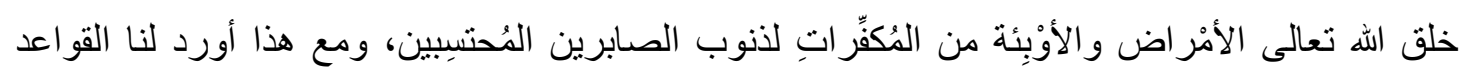

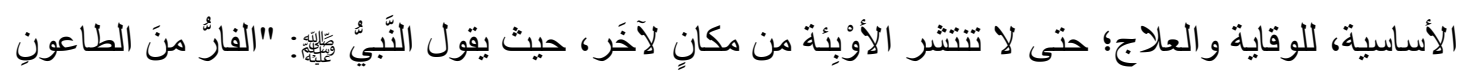
كالفارِّ منَ الزحفِ ، و الصابرُ فيه كالثهيد"، أي: أن الثخص الذي لم يهرب و يمت في أرض الوباء فهو

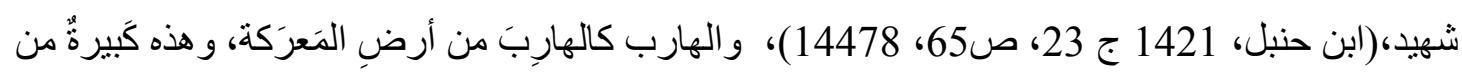

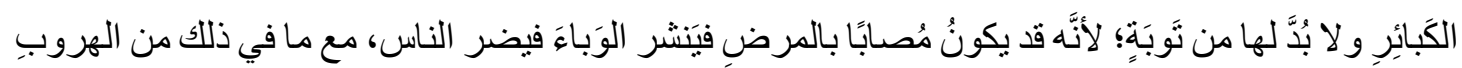

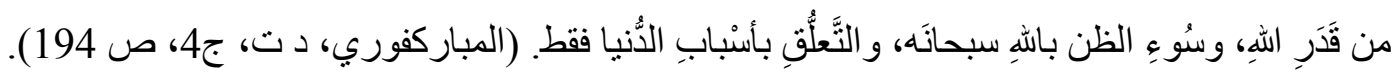
وبهذا الحديث و غيره من الأحاديث التي ملئت كتب السنة والتاريخ الإسلامي الثاهد على ذلك بلك توضح وتبين للمسلم كيف يتعامل مع الوباء وقاية و علاجا نفسيا وعمليا، كلها لم تكن محض صدفة و وإنما كنوز أنزلها الله تعالى على رسوله المصطفى صلى الله عليه وسلم، الذي علمنا إياها، وجمعها لنا الصحابة من بعده لتكون لنا ثروة علمية وإيمانية خالدة تتنظر من كل مسلم أن يفتش عنها ويستخرجها ويطبقها في حياته اليومية ليعيش بها حياة سعيدة مطمئنة، وبالبعد عنها يعيش حياة الخوف و اليأس و الحيرة، 
ولذا فقد رأيت من الأهمية بمكان در اسة أهية الوعي الديني وأثره في مو اجهة الوباء و النظر في مدى تحقيق ذلك و إمكاناته على مستوى الفرد و الجماعة.

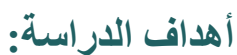

1. معرفة أهمية الوعي الديني الاعتقادية والفقهية للتصدي للوباء.

2. در اسة تطبيقية لمعرفة مدى وعي المجتمع السعودي بأحكام الوباء وتطبيقها وأثر ها عليهم. 3. التعرف على مدى التأثنر النفسي والروحي على الصحيين والمصابين وذويهم حال الوباء، لوضع الحلول الشر عية لذلك.

4. الوقوف على مدى تأثير الوازع الديني خلال الحظر على العصبية والكآبة والعنف الأسري، لوضع

$$
\text { الحلول العملية وتطبيقها واقعيا. }
$$

5. التعرف على أبرز المنافع والمضار التي واجهها المجتمع وقت الوباء. تشاؤلات البحث:

1. ما مدى نأثير الوعي بالأحكام الثرعية بالوقاية والعلاج من الوباء؟

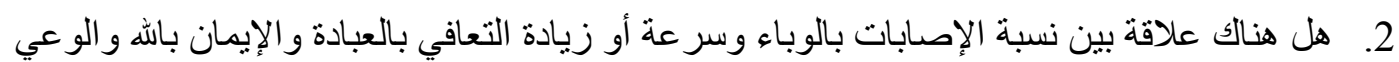

3. هل كان المجمع السعودي إجمالا على وعي بالمقومات الشرعية والإيمانية لمو اجهة الوباء؟

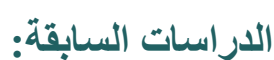
لم أعثر خلال الدر اسة على بحث علمي يبين الأسس الثر عية لمو اجهة وباء كوروناو أثره على الصحة النفسية. المبحث الأول: التُعريف بالوباء، وآثتاره. أولا: تعريف الوباء: وباء (الجمع: أوبئة)، هو انتشار مفاجئ وسريع للمرض وضاء

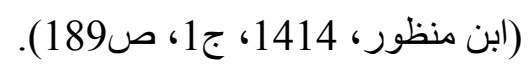

Cambridge ( ومعناه الاصطلاحي: ظهور مرض معين على عدد كبير من البشر في نفس الفترة الزمنية .2021،University ثانيا: التعريف بفيروس كورونا: وهي زمرة واسعة من الفيروسات تشمل فيروسات بمكن أن تتسبب في مجمو عة من الاعتلالات في البشر، تتر اوح ما بين نزلة البرد العادية وبين المتلازمة التنفسية الحادة الوخيمة. (منظمة الصحة العالمية، 2021). ثالثا: أبرز الآثار النفسية التي خلفتها جائحة كورونا: إن غالبية الأشخاص المعرّضين للأزمات الطبيعية، إن لم يكن كلهم، يعانون من آثار نفسية متفاوتة في الحدة، (رويترز، 2020)، أبرزها: 
الاكتئاب و الملل، بسبب العزلة، وضيق المنازل والبيوت، أو اكتظاظها و عدم تهويتها، وقد أوضح تأثير ضيق المنازل على النفس رسول الهدى محمد عليه الصلاة والسلام، حيث قال: البيث الو اسع من السعادة. (الألباني، 1408، صفحة 877). الخوف و الهلع، المؤدي إلى اليأس أو الاتتحار، أو السرقة والنهب استغلالا لحاجة الناس أو خوفا من الجوع.

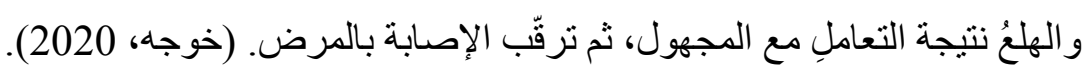
التشاؤمُ الدُفرط، و الاكتئاب و اعنبارُ الأزمة عقاباً، وتفسيرُ ها على أساس الدّين وحدَه، أو العلم فحسنب، وتأنيبُ الضدير، أو اللامبالاة والاستهنار (خوجه، 2020). (بروكسي، فيليبا 2020).

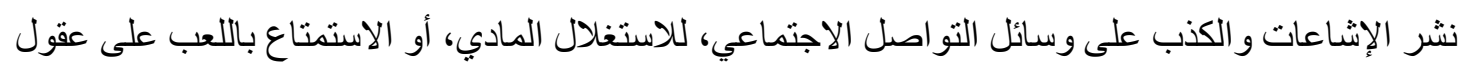
الناس و التسلية (منظمة الصحة العالمية، 2019). المبحث الثاني: مفهوم الوعي الديني لمواجهة الوباء: اختلفت وتفاوتت ردات الفعل الثر عية من البعض و التي قد تنم عن جهل بالأحكام الثر عية؛ فوقعو ا ضحايا

$$
\text { لجهلهم، وأوقعوا غير هم فيها. }
$$

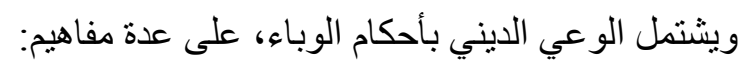

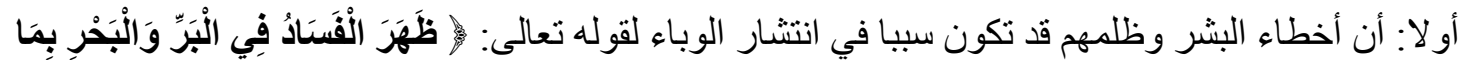

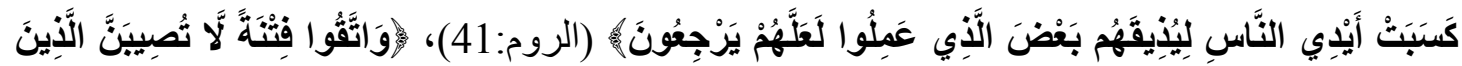

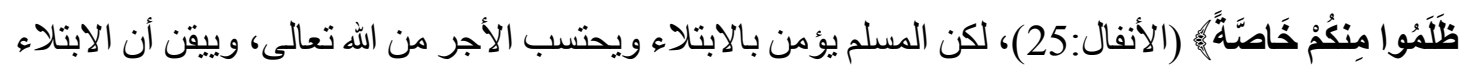

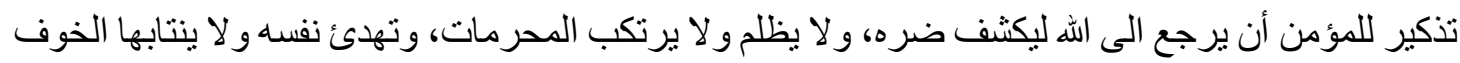
الخارج عن الطبيعي. وبناء عليه فالو اجب هو الإنابة إلى الله و الاستسلام لقضائه وقدره مطمئنا ور اضيا بالبلاء،

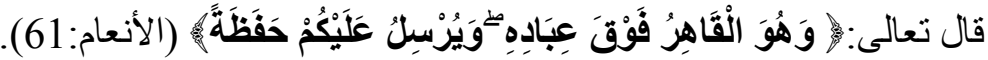

ثانيا: أن يتوكل على الله تعالى بشرط عدم الركون للأسباب وحدها أو الاعتماد على الله بدون بذل الأسباب، و التوكل هو: الاعتماد على الله وتفويض الأمر إليه (ابن منظور ج. 1414، ج11، ص صل 734-736)، (الفيومي

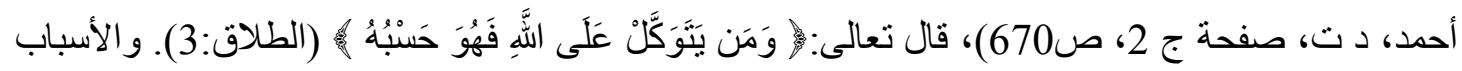

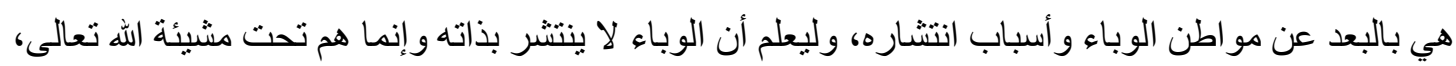
فإن شاء استمر و إن شاء أوقفه، ولذلك أكد النبي صلى الله عليه وسلم ذللك الأمر بقوله: "لا عدوى و لا طيَرة،

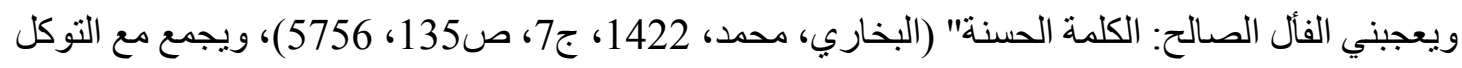

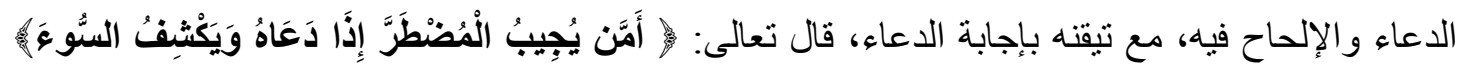

و إيضاح ذلك بييان المقصود بالأوامر الثرعية والكونية: فلله عز وجل نوعان من الأوامر :أوامر كونية،

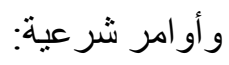


- الأوامر الكونية: وهي أمر الخلق والإيجاد، والبقاء، والنفع والضر، وهو متوجه من الله إلى جميع

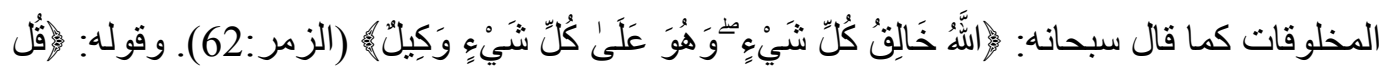

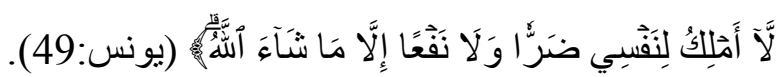
- أما الأو امر الثرعية الإلهية: فهي موجهة من اله للثقلين الإنس والجن فقطو هي الدين الذي بعث الهه به رسله، و أنزل كتبه، وهي تشمل التوحيد والإيمان، و العبادات، والمعاملات، والأخلاق، وبمقدار قوة

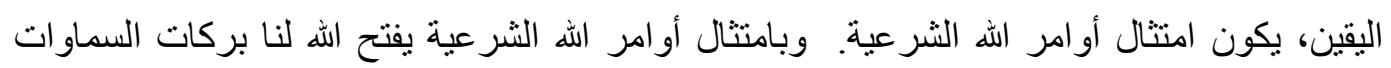
والأرض في الدنبا، ويدخلنا الجنة في الآخرة. و الأو امر الكونية لابد من وقوعها، و لا يمكن مخالفتها، وهي إما أمر رباني مباشر لازم الوقوع، كما

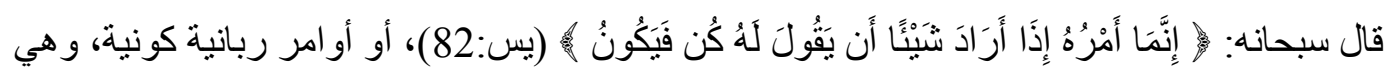
السنن الكونية التي تتكون من أسباب ونتائج يتفاعل بعضها مع بعض، ولكل سبب كوني نتيجة، قال الهاله

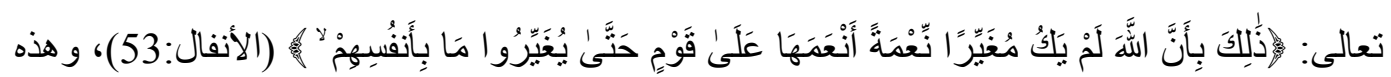

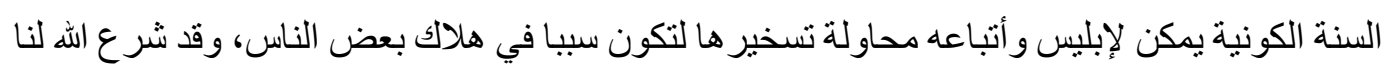

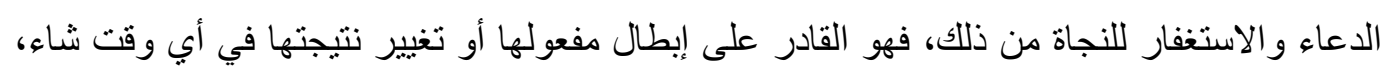

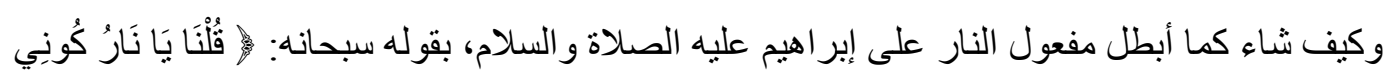

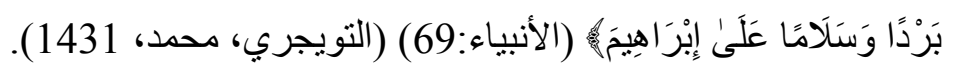

ووباء كورونا يعتبر سنة كونية، لا تخرج عن أمر الله تعلى فبسبب انتشار الفساد والمعاصي كانت النتيجة

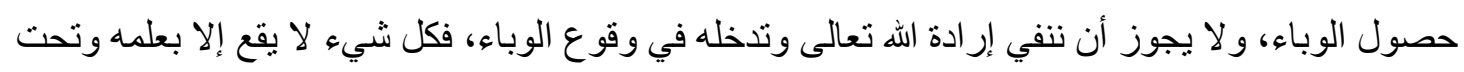

تدبيره و إحاطته.

ثالثا: البعد عن الخر افات و المعتقدات الثعبية المخالفة للاين: فتجمع الناس في دور العبادة، تسمح علميًا بانتشار

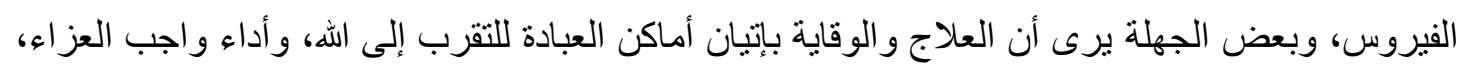
بل بارتكاب البدع المحرمة كالتوسل بالأضرحة، ويعتبرون الامتثال للتوجيهات الصحية مناقضا للإيمان

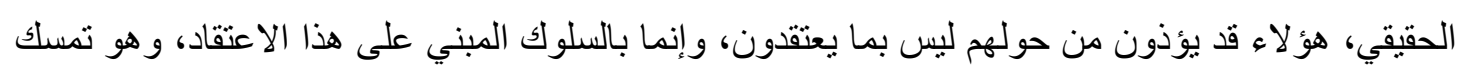
الناس بمعتقدات شعبية خاطئة، ولو تمسكوا بالعقبدة الصحيحة لكانوا أحرص على التمسك بالنصائح العلمية

$$
\text { في مواجهة المرض. (دقائق، 2020) }
$$

فالإسلام لا يمنع أي مسلم من أداء الصلاة و الذكر في البيت؛ و إنما المنع هو الذهاب إلى المسجد فقط، فالمسلم

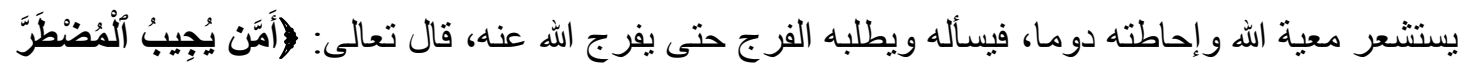

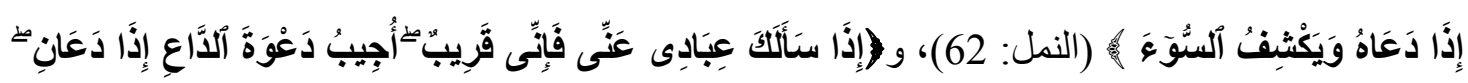
مر (البقرة:186)، فالمسلم يعلم أن الله يقبل الصلاة ويجيب الدعاء أينما كان و على أي حالة كان، و لا يخالجه

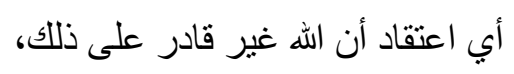




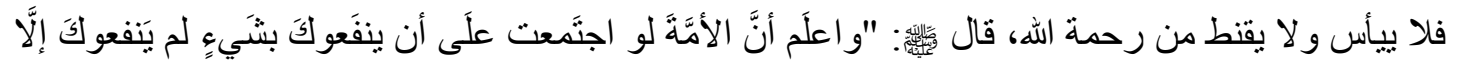

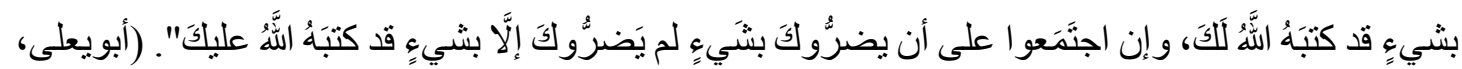

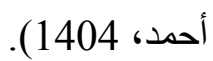

إن هدف عبادة المسلم هي رضى الله تعالى وبها يسنطعم الراحة النفسية وحلاوة الإيمان ومن العبادة التي يحبها الله تعالى مناجاته بكثف الكربة ودفع البلاء و هذه مقدور عليها في كل مكان وزمان، و اعتقاد أن الله لن يساعده إلا بنواجده في المسجد أو مكان العبادة، فغاية هذا الاعتقاد لا يمكن ان يتبادر لذهن مسلم و إن تعلق بذلك بعض الأفر اد فهو لجهاهم أو حاجة في نفسهم وليس تعبدا لله، كتعوده لحضور المسجد وصعوبة الانفكاك عنه، و هذا حال أغلب كبار السن الذين يألفون ارتباد المسجد ويحبون البقاء فيه، وليس لاعتقادهم أن ذهابهم للمسجد يقيهم من العدوى أو أن فيه علاجا من وباء كورونا، ولذلك أكد الله تعالى أن أخثى الناس لله هو العالم

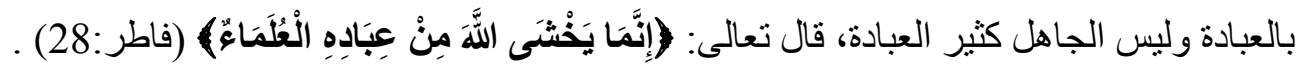
وقد أصدرت هيئة كبار العلماء بيانا بشأن الحظر، موجزه: أن من المقرَّر لدى الفقهاء أنَّ الثَّرَيعة الإسلاميَّة

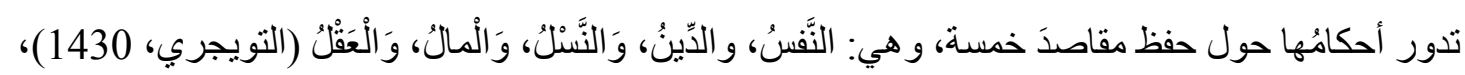

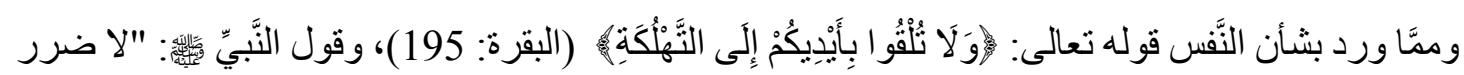

$$
\text { و لا ضرار" (البيهقي، 1424، ج6، صناك). }
$$

وبناء عليه فإن الحجر الصحي واجب شرعي عند انتشار الوباء، والأمر في ذلك مرجعه إلى الأطباء، ومؤسسات الدولة المختصة، ويجب على الجميع الاستجابة لكل التدابير التي تصدر عن الجهات الرسمية، منعا

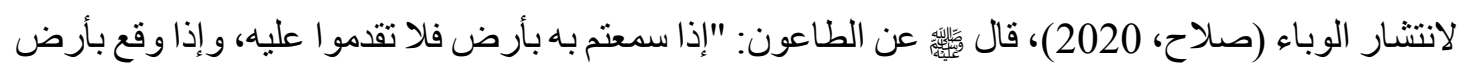

$$
\text { و أنتم بها، فلا تخرجوا فرارا منه. " (الزبيدي، 1408، ج5، ص37). }
$$

رابعا: وجوب طاعة ولي الأمر: إذا قرَّر المسؤول عدم تجمُع الناس في المساجد أو غيرها، فلا يجوز مخالفة هذا القرار سواء كان ذلك بالصلاة خلف أبواب المساجد، أو في الساحات أو الأسطح، فكل ذللك خروج صريح

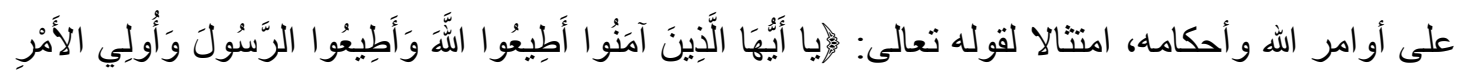
مِنْكُمر (النساء: 59)، راجع قرار مجمع الفقه الإسلامي المنعقد في دورة مؤتمره السابع بجدة في المملكة

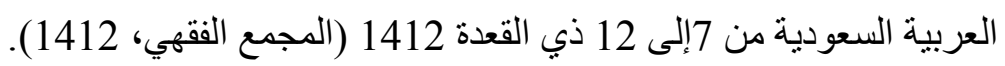

خامسا: لا يجوز شر عاً على من لديه أعر اضا أو تحققت إصابته أن برتاد المساجد، أو السفر والتسوق، لأنه

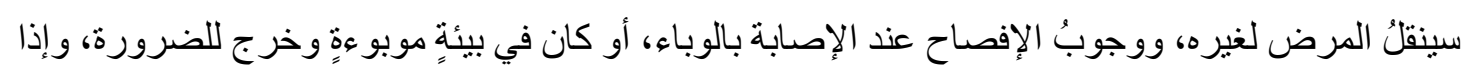
أخفى ذلك فقد ارتكب جريمتين؛ جريمة الكذب والإخفاء، وجريمة التسبب في إضر ار الأخرين بانتشار الأوبئة، وكل من يصيبه هذا المرض بسببه يتحمل الإثم، 
روى ماللك أن عمر بن الخطاب رضي الله عنه رأى امر أةً مجذومةً تطوف بالبيت فقال لها: "يَا أَََََة اللَّهِ لَ

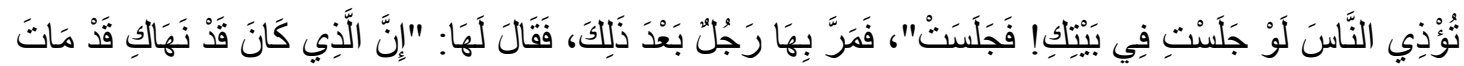

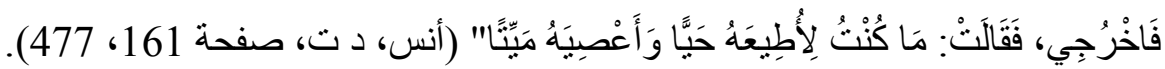
سادسا: ينبغي الاعتز ال في حالة الخوف المحقق من الإصابة “بفيروس كورونا” وليس مجرد وهم الخوف

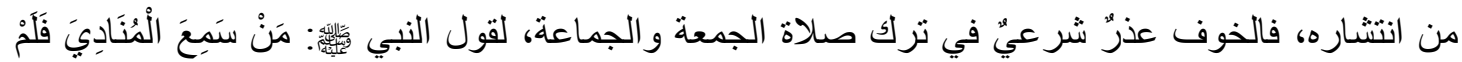

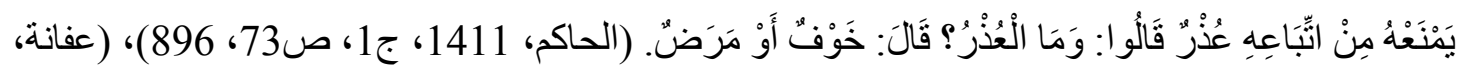

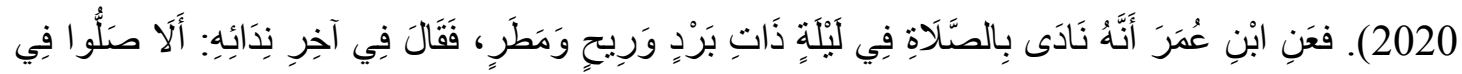

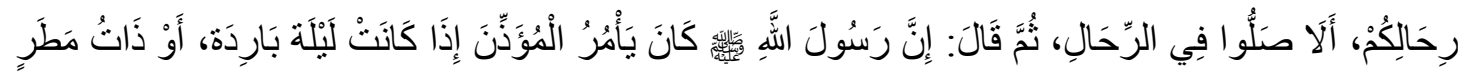

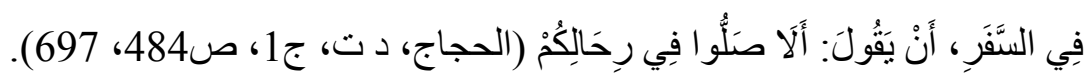

إنَّ ما يفعله بعض النَّاس نتيجة انتشار فيروس 》اكوروناه/ من تجول واختلاط يتناقض مع النُّصوص الثَّرَّيّةة، ويتعارض مع القواعد الفقهيَّة المقرَّرة؛ فقد ظهر الطاعون في زمن الخليفة عمر بن الخطاب ولم يأمر الناس بالاجتماع من أجل الدعاء أو الاستغفار أو الصلاة؛ لرفع هذا الوباء الخطير، فكل مَن يَدعو الناس

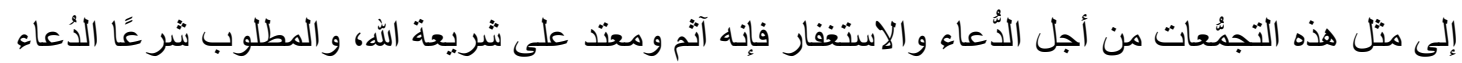

$$
\text { في بيوتهم برفع الوباء، عنهم وعن الجميع. (صلاح، 2020). }
$$

وكما نعلم أن درجات انتثار الوباء تفاوتت وردود أفعال الناس اختلفت من بيئة الى أخرى ومن مجتمع الىى آخر و لا شك أن الدين له نأثنير مباشر أو غير مباشر سريع أو بطيء قوي أو ضعيف في قلوب حامليه، فنحن

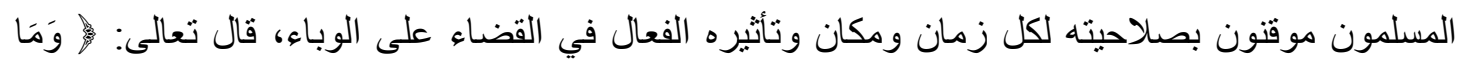

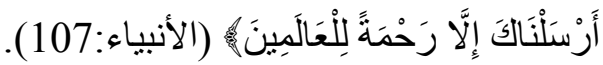

و المتفق عليه دوليا أنه في مجتمع الخليج و السعودية كانت نسب كورونا و آثار ها أقل من غير ها من الدول ومع اعتبار تأثثير درجة الحرارة على انتشار الفيروس، والاستعداد الصحي، (الخليج، النعيمي، راشد، 2020) إلا أننا نحن المسلمين لا نغفل عن العو امل الثر عية الأخرى و المهمة ليس فقط في الحد من انتشار الوباء بل بإيقافه أيضاوذللك لأن جو هر عبادة المسلمين هي وقاية قبل أن تكون علاجا، و أعزو قلة انتشار الوباء إلى:

$$
\begin{aligned}
& \text { • الإيمان بقضاء الله وقدره، و التحصن بذكره، و التوكل عليه مع بذل السبب. } \\
& \text { • النظافة و الطهارة من وضوء و غسل و إز الة النجاسة. } \\
& \text { • البعد عن الاختلاط خاصة بين الجنسين وحدود التجمعات العامة. } \\
& \text { • عدم ارتكاب الإثم بأذية الآخرين ونشر العدوى. }
\end{aligned}
$$


المبحث الثالث: منهجية الدراسة وإجراءاتها:

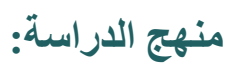
لتحقيق أهداف الدراسة والإجابة على تساؤ لاتها استخدمت الباحثة المنهج الوصفي المسحي؛ وهو كما يعرفه (العساف ،2012،ص 179) بأنه المنهج "الذي يتم بواسطة استجو اب جميع أفر اد مجتمع البحث أو عينة كبيرة منهم، وذلك بهدف وصف الظاهرة المدروسة من حيث طبيعتها ودرجة وجودها فقط، دون أن يتجاوز ذلك إلى بلى در اسة العلاقة أو استنتاج الأسباب مثناً"، و الذي يعتبر من أكثر المناهج ملاءمةً للار اسة الحالية، لاعتماده على وده وصف الو اقع الحقيقي للظاهرة ومن ثم تحليل النتائج وبناء الاستتناجات في ضوء الو الو اقع الحالي. • مجتمع الدراسة: يتكون مجتمع الدر اسة الحالية من جميع أنحاء السعودية و البالغ عددهم (500) خلال

$$
\text { فترة إجر اء الدر اسة. }
$$

• عينة الار اسةة: نم أخذ عينة عشو ائية بسيطة مكونة من (500) مفردة. • خصائص أفراد الدراسة: نم تحديد عدد من المتغيرات الرئيسية لوصف أفراد الدراسة، والتي لها مؤشرات دلالية على نتائج الدراسة، بالإضافة إلى أنها تعكس الخلفية العلمية لأفراد الدراسة، وتساعد على إرساء الدعائم التي تُبنى عليها التحلبلات المختلفة المتعلقة بالدر اسة، وتفصيل ذلك فيما يلي:

جدول رقم (1-3) توزيع أفراد الدراسة وفق المتغيرات الأولية

\begin{tabular}{|c|c|c|}
\hline النسبة \% & التكرار & العمر \\
\hline 76.2 & 381 & 10 - ب سنة \\
\hline 20.0 & 100 & •r. - ع سنة \\
\hline 3.0 & 15 & •ــ •. \\
\hline 0.8 & 4 & 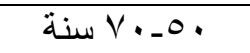 \\
\hline النسبة \% & التكرار & الحالة الاجتماعية \\
\hline 90.0 & 450 & عازب \\
\hline 8.4 & 42 & منزوج \\
\hline 1.6 & 8 & مطلق \\
\hline النسبة \% & التكرار & الأطفال \\
\hline 90.2 & 451 & لا يوجد \\
\hline 5.4 & 27 & $r_{-1}$ \\
\hline 4.4 & 22 & ب فأكثر \\
\hline النسبة \% & التكرار & الحالة المادية \\
\hline 10.8 & 54 & دخل ضعيف \\
\hline
\end{tabular}




\begin{tabular}{|c|c|c|}
\hline 81.2 & 406 & دخل متوسط \\
\hline 8.0 & 40 & دخل عالي \\
\hline النسبة \% & التكرار & هل منزلك \\
\hline 35.0 & 175 & و واسع \\
\hline 59.0 & 295 & وسط \\
\hline 6.0 & 30 & ضيق \\
\hline النسبة \% & التكرار & من يقطن معك في المنزل \\
\hline 8.4 & 42 & زوجتي و أطفالي \\
\hline 4.2 & 21 & أمي و أبي \\
\hline 85.2 & 426 & أمي و أبي و أخوتي \\
\hline 2.2 & 11 & امي و اخو اني \\
\hline$\% 100$ & 500 & المجموع \\
\hline
\end{tabular}

• أداة الـدر اســــة: تم استخدام الاستبانة أداةً لجمع البيانات؛ وذلك نظر اً لمناسبتها لأهداف الدر اسة،

$$
\text { ومنهجها، ومجتمعها، وللإجابة على تساؤ لاتها. }
$$

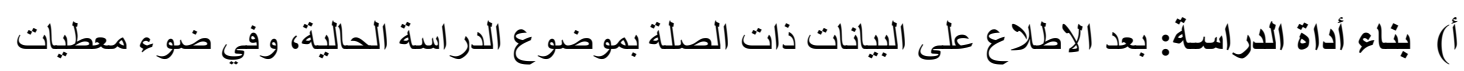
وتسـاؤ لات الدر اسـة و أهدافها تم بناء الأداة (الاستبانة)، وتكونت في صـورتها النهائية من ثلاثة أجز اء. وفيما

يلي عرض للإجر اءات المتبعة للتحقق من صدقها، وثباتها:

1- القسـم الأول: يحتوي على مقدمة تعريفية بأهداف الدر اسـة، ونوع البيانات التي يود جمعها من أفر اد

عينة الدر اسـة، مع تقديم الضــــان بسـرية المعلومات، و التعهد باســخدامها لأغر اض البحث العلمي

فقط.

2- القسم الثاني: يحتوي على البيانات الأولية الخاصة بأفر اد عينة الدر اسة.

3- القسم الثالث: ويتكون من الأسئلة المتعلقة بمحاور الدر استة.

ب) صدق أداة الاراسـة: أي التأكد من أنها تقيس ما أعدت كما يقصد به شمول الاستبانة لكل العناصر التي التي تدخل في التحليل من ناحية، ووضوح عبار اتها من ناحية أخرى، بحيث تكون مفهومة لكل من يستخدمها وقد تم التأكد من صدق أداة الدر اسة من خلال: 1- الصدق الظاهري لأداة الاراسة (صدق المحكّمين): للتعرف على مدى صدق الاستبانة، و التأكد من

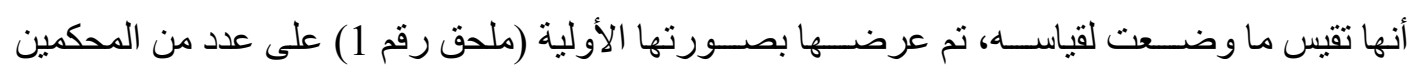
المختصين في موضوع الدراسة، حيث وصل عدد المحكمين إلى (5) محكمين (ملحق رقم 2)، وقد طُلب من السادة المحكمين تقييم جودة الاستبانة، من حيث قدرتها على قياس ما أعدت لقياسه، 
و الحكم على مدى ملاءمتها لأهداف الدر اسة، وذللك من خلال تحديد وضوح العبار ات، و انتمائها للمحور،

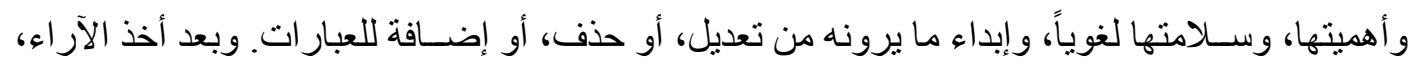
و الملحوظات، تم إجر اء التعديلات اللازمة التي اتفق عليها المحكمين، ومن ثم إخر اج الاستبانة بصورتها النهائية (ملحق رقم 2).

2- إجراءات تطبيق الاراسـة: بعد التأكد من صــدق (الاسـتبانة) وثباتها، وصـلاحيتها للتطبيق، قامت الباحثة بتطبيقها ميدانياً باتباع الخطو ات النات النية:

$$
\text { - - ت توزيع الاستبانة إلكترونياً. }
$$$$
\text { - - مع الاستبانات، وقد بلغ عددها (500) استبانة. }
$$

• أسـاليب المعالجة الإحصائية: لتحقيق أهداف الدراسة، وتحليل البيانات التي تم تجميعها، فقد تم استخدام Statistical العديد من الأسـاليب الإحصــائية المناسـبة باسـتخدام الحزم الإحصــائية للعلوم الاجتماعية Package for Social Sciences وبعد ذلك تم حساب المقاييس الإحصائية التالية: التكر ارات، و النســب المئوية؛ للتعرف على خصــائص أفر اد الدر اســة، وتحديد اســتجاباتهم تجاه عبار ات المحاور الرئيسة التي تتضنهنها أداة الدر اسة. • تحليل نتائج الدراسـة وتفسير ها: يتنتاول هذا الفصل عرضا تفصيلياً للنتائج التي توصلت إليها الدر اسة الحالية، وذلك من خلال الإجابة عن أسئلة الدر اسة وفق المعالجات الإحصائية المناسبة، ومن ثم تفسير هذه

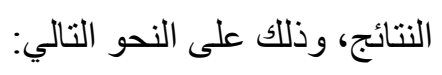

1 ) ما هو شعورك عندما سمعت بـوباء كورونا:

جدول رقم (4-1) توزيع أفر اد الدر اسة وفق متغير ما هو شعورك عندما سمعت بـوباء كورونا

\begin{tabular}{|c|c|c|}
\hline النسبة \% & التكرار & ما هو شعورك عندما سمعت بـوباء كورونا \\
\hline 21.0 & 105 & الخوف \\
\hline 54.8 & 274 & القلق و التوتر \\
\hline 24.2 & 121 & شعور طبيعي \\
\hline$\% 100$ & 500 & المجموع \\
\hline
\end{tabular}

يتضـح من الجدول رقم (4 -1) أن (274) من أفراد الدر اسة يمثلون ما نسبته 54.8٪ شعور هم عندما سمعو ا بوباء كورونا القلق و التوتر، أنو، بينما (121) منهم يمثلون 24.2٪ من إجمالي أفر اد الدر اسة شعور هم طبيعي عندما سمعو ا بـــوباء كورونا، و (105) منهم يمنلون 21.0٪ من إجمالي أفر اد الدر اسة شعور هم عندما سمعو ا بوباء كورونا الخوف. 
جدول رقم (4-2) توزيع أفراد الدراسة وفق متغير ماهي ردة فعلك

\begin{tabular}{|c|c|c|}
\hline النسبة \% & التكرار & ماهي ردة فعلك \\
\hline 94.8 & 474 & الحذر و التجاوب مع الأنظمة \\
\hline 4.0 & 20 & أحيانا في بعض الأمور \\
\hline 1.2 & 6 & التردد و الحيرة \\
\hline$\% 100$ & 500 & المجموع \\
\hline
\end{tabular}

يتضح من الجدول رقم (4 -2) أن (474) من أفر اد الدر اسة يمثلون ما نسبته 94.8٪ ردة فعلهم الحذر

و التجاوب مع الأنظمة، بينما (20) منهم يمثلون ما نسـبته 4.0٪ من إجمالي أفر اد الدر اســة ردة فعلهم أحيانا في بعض الأمور، و (6) منهم يمثلون ما نسبته 1.2\% من إجمالي أفر اد الدر اسة ردة فعلهما التردد و الحيرة. 3) هل تعرف ماهي السنة النبوية الواردة للوقاية من الوباء: جدول رقم (4-3) توزيع أفراد الدراسة وفق متغير هل تعرف ماهي السنة النبوية الواردة للوقاية من الوباء

\begin{tabular}{|c|c|c|}
\hline النسبة \% & التكرار & هل تعرف ماهي السنة النبوية الواردة للوقاية من \\
\hline 26.6 & 133 & $\bar{\gamma}$ \\
\hline 25.8 & 129 & ربما \\
\hline 47.6 & 238 & نعم \\
\hline$\% 100$ & 500 & المجموع \\
\hline
\end{tabular}

يتضـح من الجدول رقم (4 -3) أن (238) من أفر اد الدر اسـة بمثلون ما نسبته 47.6\% بعرفون السنة النبويـة الواردة للوقايـة من الوبـاء، بينما (133) منهم يمثلون 26.6٪ من إجمالي أفر اد الدر اســـة لا يعرفون الســنة الواردة للوقاية من الوباء، و (129) منهم يمثلون ما نســبته 25.8٪ من إجمالي أفر اد الدر اســـة ربما

$$
\text { يعرفون السنة الواردة للوقاية من الوباء. }
$$

4) هل شعرت في فترة الحظر بالسآمة لارجة عدم الرغبة في أداء الواجبات المنزلية: جدول رقم (4-4) توزيع أفراد الدراسة وفق متغير هل شعرت في فترة الحظر بالسآمة لدرجة عدم الرغبة في أداء الواجبات المنزلية مئية

\begin{tabular}{|c|c|c|}
\hline النسبة \% & التكرار & هل شعرت في فترة الحظر بالسآمة لارجة عدم الرغبة في أداء \\
\hline 29.4 & 147 & $y$ \\
\hline 20.4 & 102 & ربما \\
\hline
\end{tabular}




\begin{tabular}{|c|c|c|}
\hline 50.2 & 251 & نعم \\
\hline \%100 & $\mathbf{5 0 0}$ & المجموع \\
\hline
\end{tabular}

يتضـح من الجدول رقم (4 -4) أن (251) من أفر اد الدر اسة يمتلون ما نسبته 50.2\% شعروا في فترة

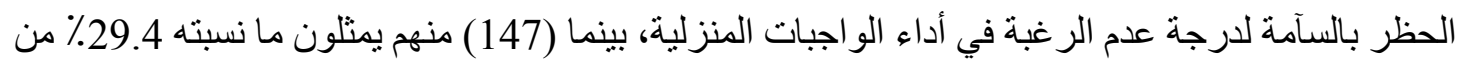

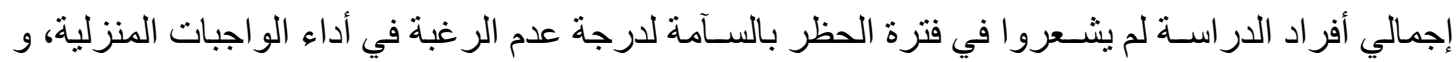

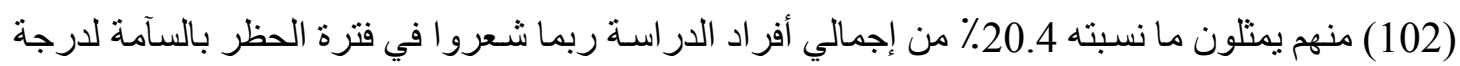

$$
\text { عدم الرغبة في أداء الواجبات المنزلية. }
$$

5) هل تشعر أن فتره الحظر زادت من عصبيتلك و انفعالك:

جدول رقم (4-5) توزيع أفراد الاراسة وفق متغير هل تثشعر أن فتره الحظر زادت من عصبيتك وانفعالك

\begin{tabular}{|c|c|c|}
\hline النسبة \% & 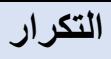 & هل تشعر أن فتره الحظر زادت من عصبيتك و انفعالكك \\
\hline 54.8 & 274 & $y$ \\
\hline 45.2 & 226 & نعم \\
\hline$\% 100$ & 500 & المجموع \\
\hline
\end{tabular}

يتضـح من الجدول رقم (4 -5) أن (274) من أفراد الدر اسـة يمثلون ما نسبته 54.8\% لا يشعرون أن

فترة الحظر زادت من عصـــبيتهم و انفعالهم، بينما (226) منهم يمثلون ما نســـبته 45.2٪ من إجمالي أفراد

الدراسة يشعرون أن فترة الحظر زادت من عصبيتهر.

$$
\text { 6) إذا كان الجواب نعم فالسبب هو: }
$$

\begin{tabular}{|c|c|c|}
\hline النسبة \% & التكرار & إذا كان الجواب نعم فالسبب هو \\
\hline 39.4 & 89 & عدم وجود تسلية \\
\hline 28.3 & 64 & الجلوس لوقت طويل على الأجهزة \\
\hline 4.9 & 11 & ضيق المنزل وكثرة الاولاد \\
\hline 3.1 & 7 & عدم القدرة على توفير الطلبات \\
\hline 24.3 & 55 & غير ذللك \\
\hline$\% 100$ & 226 & المجموع \\
\hline
\end{tabular}

جدول رقم (4-6) توزيع أفراد الدراسة وفق متغير إذا كان الجواب نعم فالسبب هو

يتضـح من الجدول رقم (4 -6) أن (89) من أفر اد الدر اسـة الذين يثـعرون أن فترة الحظر زادت من

عصــبيتهم و انفعالهم يمثلون 39.4\% كان بســبب عدم وجود تســلية، بينما (64) منهم يمثلون 28.3\% من

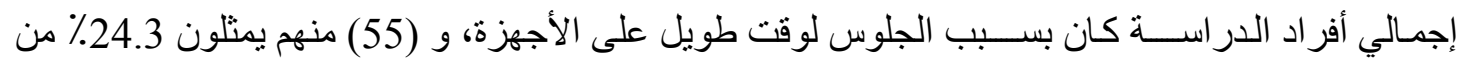
إجمالي أفر اد الدراسة زادت عصبيتهم بسبب غير ذللك، 
و (11) منهم يمثلون ما نسـبته 4.9\% ز ادت عصــيتهم بســبب ضــيق المنزل وكثره الاو لاد، و (7) منهم يمثلون 3.1٪ من إجمالي أفراد الدراسة زادت عصبيتهم بسبب عدم القدرة على توفير الطلبات. 7) هل تعرف شخصا أو أنت تسبب بالأذى للغير بسبب العنف: جدول رقم (4-7) توزيع أفراد الدراسة وفق متغير هل تعرف شخصا أو انت تسبب بالأذى للغير بسبب العنف

\begin{tabular}{|c|c|c|}
\hline النسبة \% & التكرار & هل تعرف شخصا أو انت تسبب بالأذى للغير بسبب \\
\hline 74.8 & 374 & $y$ \\
\hline 25.2 & 126 & نعم \\
\hline$\% 100$ & 500 & المجموع \\
\hline
\end{tabular}

يتضــح من الجدول رقم (4 -7) أن (374) من أفر اد الدر اسـة يمثلون 74.8\% لا يعرفون شـخصــا أو أنهم تسببو ا بالأذى للغير بسبب العنف، بينما (126) منهم يمثلون 25.2٪ من إجمالي أفر اد الدراسـة يعرفون شخصا أو أنهم تسبيو ا بالأذى للغير بسبب العدى بلفئ. 8) جدول رقم (4-8) توزيع أفراد الدراسة وفق متغير إذا كاتت الإجابة نعم فمع من

\begin{tabular}{|c|c|c|}
\hline النسبة \% & الت التكرار & إذا كاتت الإجابة نعم فمع من \\
\hline 29.4 & 37 & 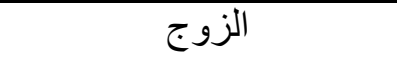 \\
\hline 15.1 & 19 & الأولاد \\
\hline 27.0 & 34 & الأخوة \\
\hline 23.0 & 29 & الو الدين الدين \\
\hline 5.6 & 7 & اخري \\
\hline$\% 100$ & 126 & المجموع \\
\hline
\end{tabular}

يتضــح من الجدول رقم (4 -8) أن (37) من أفر اد الدر اســة الذين يعرفون شـخصــا أو أنهم تسـببوا بالأذى للغير بسـبب العنف يمثلون ما نسـبته 29.4٪ من الذين يعرفون شـخصـا أو أنهم تسببوا بالأذى للغير بسبب العنف عنفهم مع الزوج، بينما (34) منهم يمثلون ما نسبته 27.0٪ من إجمالي أفراد الدر اسة من الذين يعرفون شـخصـا أو أنهم تسبيو ا بالأذى للغير بسبب العنف عنفهم مع الأخوة، و (29) منهم يمثلون ما نسبته 23.0٪ من إجمالي أفر اد الدر اسـة من الذين يعرفون شخصـا أو أنهم تسبيوا بالأذى للغير بسبب العنف عنفهم مع الو الدين، و (19) منهم يمثلون ما نسـبته 15.1\% من إجمالي أفر اد الدر اسـة من الذين يعرفون شـخصـا أو أنهم تسببوا بالأذى للغير بسبب العنف عنفهم مع الأو لاد، و (7) منهم يمثلون ما نسبته 5.6٪ من إجمالي أفراد الدر اسة من الذين يعرفون شخصا أو أنهم تسببو ا بالأذى للغير بسبب العنف عنفهم مع اخرين. 
جدول رقم (4-9) توزيع أفراد الاراسة وفق متغير كيف كان العنف

\begin{tabular}{|c|c|c|}
\hline النسبة \% & التكرار & كيف كان العنف \\
\hline 38.1 & 48 & مجرد صر اخ وشتم \\
\hline 38.9 & 49 & ضرب باليد و الدفع \\
\hline 15.1 & 19 & ضرب بأدو ات وقذف بالأشياء \\
\hline 7.9 & 10 & غير ذللك \\
\hline$\% 100$ & 126 & المجموع \\
\hline
\end{tabular}

يتضـح من الجدول رقم (4 -9) أن (49) من أفر اد الدر اســة الذين يعرفون شـخصــا أو أنهم تشـببوا

بالأذى للغير بسبب العنف يمثلون ما نسـبته 38.9٪ كان العنف ضـرب باليد و الدفع، بينما (48) منهم يمثلون ما نسبته 38.1٪ من إجمالي أفر اد الدر اسـة من الذين يعرفون شخصا أو أنهم تسببو ا بالأذى للغير كان مجرد

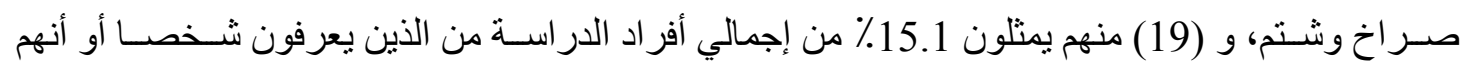
تسببو ا بالأذى للغير كان ضرب بأدوات وقذف بالأشياء، و (10) منهم يمثلون 7.9٪ كان تعبير هم عن العنف بطرق أخرى.

10)وسائل الترفيه التي كنت تزاولها في فترة الحظر: جدول رقم (4-4) توزيع أفراد الدراسة وفق متغير وسائل الترفيه التي كنت تزاولها في فترة الحظر

\begin{tabular}{|c|c|c|}
\hline النسبة \% & التكر ار & وسائل الترفيه التي كنت تز اولها في فترة الحظر \\
\hline 23.4 & 117 & رياضة المشي و اللعب \\
\hline 66.8 & 334 & مشّاهده التلفاز ووسائل التو اصل الاجتماعي \\
\hline 3.2 & 16 & زيارة قريب \\
\hline 6.6 & 33 & غير ذللك \\
\hline$\% 100$ & 500 & المجموع \\
\hline
\end{tabular}

يتضح من الجدول رقم (4 -10) أن (334) من أفراد الدر اسة يمثلون ما نسبته 66.8\% وسائل الترفيه

التي كانو ايزاولونها في فترة الحظر مشـاهده التلفاز ووسـائل التو اصل الاجتماعي، بينما (117) منهم يمثلون

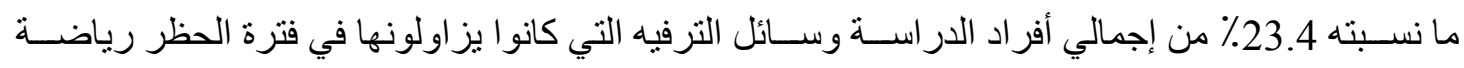

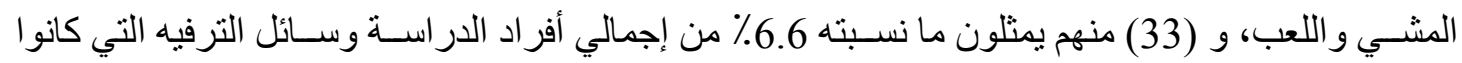
يز اولونها في فترة الحظر غير ذلك، و (16) منهم يمثلون ما نسـبنه 3.2٪ من إجمالي أفراد الدراســة وسـائل الترفيه التي كانو ا بز اولونها في فترة الحظر زيارة قريب. 
11 ) هل كان الالتزام بالوقاية عملية:

جدول رقم (11-4) توزيع أفراد الدراسة وفق متغير هل كان الالتزام بالوقاية عملية

\begin{tabular}{|c|c|c|}
\hline النسبة \% & التكرار & هل كان الالنزام بالوقاية عملية \\
\hline 23.6 & 118 & سهلة \\
\hline 19.8 & 99 & صعبة \\
\hline 56.6 & 283 & متوسطة \\
\hline$\% 100$ & 500 & المجموع \\
\hline
\end{tabular}

يتضـح من الجدول رقم (4 -11) أن (283) من أفراد الدر اسة يمثلون ما نسبته 56.6٪ يرون الالتزام

بالوقاية عملية متوسطة، بينما (118) منهم يمثلون ما نسبته 23.6٪ من إجمالي أفر اد الدر اسة يرون الالتز ام بالوقاية عملية سـهلة، و (99) منهم يمثلون ما نسبته 19.8٪ من إجمالي أفر اد الدر اسة يرون الالتز ام بالوقاية عملية صعبة.

12) هل قمت بالمساعدة في نشر الوعي والوقاية من الوباء: جدول رقم (4-12) توزيع أفراد الاراسة وفق متغير هل قمت بالمساعدة في نشر الوعي والوقاية من الوباء

\begin{tabular}{|c|c|c|}
\hline النسبة \% & 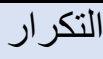 & هل قمت بالمساعدة في نشر الوعي و الوقاية من الوباء \\
\hline 33.8 & 169 & $y$ \\
\hline 47.8 & 239 & 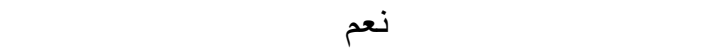 \\
\hline 18.4 & 92 & حاولت ولم أستطيع \\
\hline$\% 100$ & 500 & 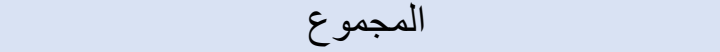 \\
\hline
\end{tabular}

يتضـــح من الجدول رقم (4 -12) أن (239) من أفراد الدر اســـة يمتلون مـا نســـبته 47.8\% قاموا بالمسـاعدة في نشـر الوعي و الوقاية من الوباء، بينما (169) منهم يمثلون ما نسـبته 33.8٪ من إجمالي أفراد

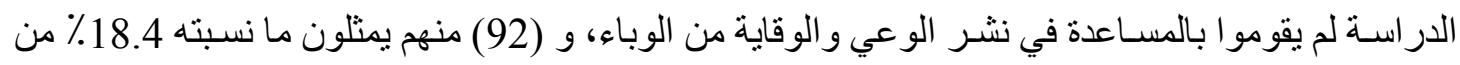
إجمالي أفر اد الدر اسة حاولوا المساعدة في نشر الوعي و الوقاية من الوباء ولم بينطيعو ا. 13) هل عادت عليك جائحة كورونا:

جدول رقم (4-4) توزيع أفراد الدراسة وفق متغير هل عادت عليك جائحة كورونا

\begin{tabular}{|c|c|c|}
\hline النسبة \% & التكر ار & هل عادت عليك جائحة كورونا \\
\hline 24.6 & 123 & بالنفع \\
\hline 8.0 & 40 & بالضرر \\
\hline 19.4 & 97 & لا شيء \\
\hline 48.0 & 240 & بالنفع و الضرر \\
\hline
\end{tabular}




\begin{tabular}{|c|c|c|}
\hline$\% 100$ & 500 & المجموع \\
\hline
\end{tabular}

يتضـح من الجدول رقم (4 -13) أن (240) من أفر اد الدر اسـة يمثلكون ما نسبته 48.0\% عادت عليهم جائحة كورونا بالنفع و الضرر، بينما (123) يمثلون ما نسبته 24.6٪ من إجمالي أفر اد الدراسة عادت عليهم جائحة كورونا بالنفع، و (97) يمثلون ما نسبته 19.4\% من إجمالي أفر اد الدر اسة عادت عليهم جائحة كورونا بلا شيء، و (40) يمثلون ما نسبته 8.0٪ من إجمالي أفر اد الدر اسة عادت عليهم جائحة كورونا بالضرر.

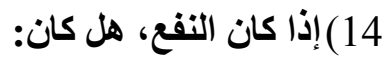

جدول رقم (4-14) توزيع أفراد الدراسة وفق متغير إذا كان النفع، هل كان

\begin{tabular}{|c|c|c|}
\hline النسبة \% & التكرار & إذا كان النفع، هل كان \\
\hline 16.5 & 60 & مادياً \\
\hline 42.1 & 153 & اجتماعياً \\
\hline 28.1 & 102 & دينياً \\
\hline 5.5 & 20 & نفسياً \\
\hline 7.7 & 28 & 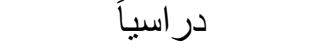 \\
\hline$\% 100$ & 363 & المجموع \\
\hline
\end{tabular}

يتضح من الجدول رقم (4 -14) أن (153) من أفر اد الدر اسة الذين عادت عليهم جائحة كورونا بالنفع يمثلون ما نســبته 42.1\% من الذين عادت عليهم جائحة كورونا بالنفع كان النفع اجتماعياً، بينما (102) منهم

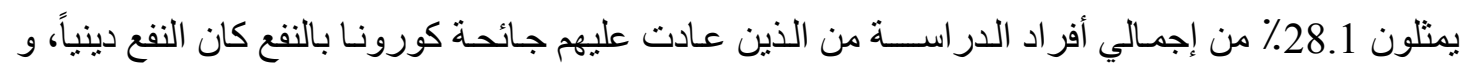
(60) منهم يمثلون 16.5\% من إجمالي أفر اد الدراســـة من الذين عادت عليهم جائحة كورونا بالنفع كان النفع مادياً، و (28) منهم يمثلون 7.7٪ من إجمالي أفر اد الدر اسـة من الذين عادت عليهح جائحة كورونا بالنفع كان النفع در اسـياً، و (20) منهم يمثلون 505٪ من إجمالي أفر اد الدر اســة من الذين عادت عليهم جائحة كورونا بالنفع كان النفع نفسياً.

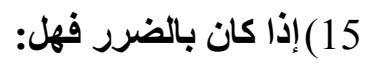

جدول رقم (15-4) توزيع أفراد الدراسة وفق متغير إذا كان بالضرر فهل

\begin{tabular}{|c|c|c|}
\hline النسبة \% & التكر ار & إذا كان بالضرر فهل \\
\hline 7.1 & 20 & أصبت بالمرض \\
\hline 17.9 & 50 & فقدت أحداً ممن تعرف \\
\hline 10.7 & 30 & خسارة مالية \\
\hline 64.3 & 180 & غير ذللك \\
\hline$\% 100$ & 280 & المجموع \\
\hline
\end{tabular}


يتضـــح من الجدول رقم (4 -17) أن (180) من أفراد الدر اســـة الذين عادت عليهم جائحة كورونا بالضـرر يمثلون ما نسـبته 64.3٪ من الذين عادت عليهم جائحة كورونا بالنفع كان الضـرر غير ذللك، بينما (50) منهم يمثلون 17.9٪ من إجمالي أفر اد الدر اســـة من الذين عادت عليهم جائحة كورونا بالضــرر كان الضـــرر فقدت أحداً ممن تعرف، و (30) منهم يمثلون 10.7٪ من إجمالي أفراد الدراســــة من الذين عادت عليهم جائحة كورونا بالضـرر كان الضـرر خسـارة مالية، و (20) منهم يمتلون ما نسـبته 7.1 7. من إجمالي أفر اد الدر اسة من الذين عادت عليهم جائحة كورونا بالضرر كان الضرر أصبت بالمرض.

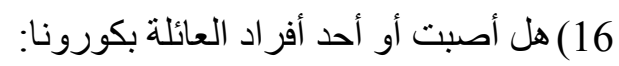

جدول رقم (4-16) توزيع أفراد الدراسة وفق متغير هل أصبث أو أحد أفراد العائلة بكورونـا

\begin{tabular}{|c|c|c|}
\hline النسبة \% & 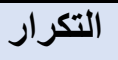 & هل أصبت أو أحد أفراد العائلة بكورونـا \\
\hline 64.6 & 323 & $\bar{\gamma}$ \\
\hline 35.4 & 177 & 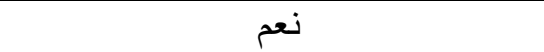 \\
\hline$\% 100$ & 500 & المجموع \\
\hline
\end{tabular}

يتضـح من الجدول رقم (4 -18) أن (323) من أفر اد الدر اسـة يمتلون ما نسبته 64.6\% لم يصيبوا أو

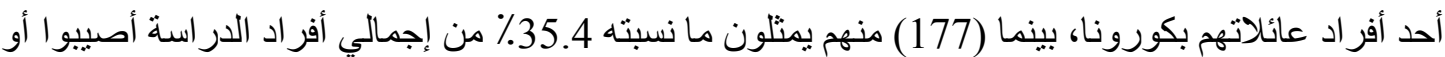
أحد أفر اد عائلاتهم بكورونا. 17) إذا كان الجواب نعم فالسبب هو: جدول رقم (4-17) توزيع أفراد الدراسة وفق متغير إذا كان الجواب نعم فالسبب هو

\begin{tabular}{|c|c|c|}
\hline النسبة \% & التكر ار & إذا كان الجو اب نعم فالسبب هو \\
\hline 23.2 & 41 & الخروج للعمل \\
\hline 11.9 & 21 & الخروج لثر اء مستلزمات \\
\hline 5.1 & 9 & الخروج للزيارة \\
\hline 27.1 & 48 & زيارة الأقارب \\
\hline 32.8 & 58 & غير ذللك \\
\hline$\% 100$ & 177 & المجموع \\
\hline
\end{tabular}

يتضـــح من الجدول رقم (4 -17) أن (58) من أفر اد الدراســة الذين أصــيو ا أو أحد أفراد عائلاتهم بكورونا يمثلون ما نسـبته 32.8٪ من الذين أصــيبو أو أحد أفر اد عائلاتهم بكورونا بسـبـ غير ذلك، بينما (48) منهم يمثلون ما نســبته 27.1\% من إجمالي أفر اد الدر اســـة من الذين أصـــيبو ا أو أحد أفراد عائلاتهم بكورونا بسـبب زيارة الأقارب، و (41) منهم بمثلون ما نسـبته 23.2٪ من إجمالي أفر اد الدر اسـة من الذين

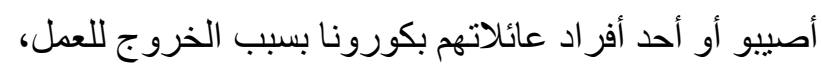


و (21) منهم يمثلون ما نسـبته 11.9٪ من إجمالي أفراد الدر اســة من الذين أصــيبو ا أو أحد أفراد عائلاتهم بكورونـا بــبب الخروج لثــر اء مسـتلزمات، و (9) منهم يمتلون 5.1٪ من إجمالي أفراد الدر اسـة من الذين أصيبو أو أحد أفر اد عائلاتهم بكورونا بسبب الخروج للزيارة. 18) هل ندمت:

جدول رقم (18-4) توزيع أفراد الدراسة وفق متغير هل ندمت

\begin{tabular}{|c|c|c|}
\hline النسبة \% & التكر ار & هل ندمت \\
\hline 66.7 & 118 & $\bar{\gamma}$ \\
\hline 17.5 & 31 & ربما \\
\hline 15.8 & 28 & نعم \\
\hline$\% 100$ & 177 & المجمو ع \\
\hline
\end{tabular}

يتضــح من الجدول رقم (4 -18) أن (118) من أفر اد الدراسـة الذين أصـيليو ا أو أحد أفراد عائلاتهم

بكورونا يمثلون ما نسبته 66.7٪ من الذين أصيبو ا أو أحد أفر اد عائلاتهم بكورونا لم يندمو ا، بينما (31) منهم يمثلون ما نسـبته 17.5٪ من إجمالي أفر اد الدراســة من الذين أصــيوا أو أحد أفراد عائلاتهم بكورونا ربما

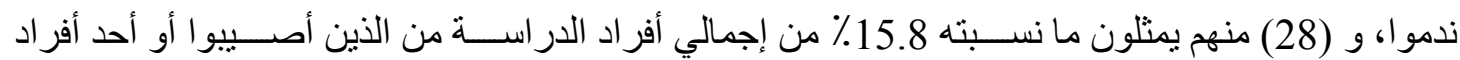
عائلاتهم بكورونا ندموا. 19)ماذا شعرت بعد العلم بالإصابة:

جدول رقم (19-4) توزيع أفراد الدراسة وفق متغير ماذا شعرت بعد العلم بالإصابة

\begin{tabular}{|c|c|c|}
\hline النسبة \% \% & التكر ار & ماذا شعرت بعد العلم بالإصـابة \\
\hline 6.2 & 11 & الخوف من الموت \\
\hline 15.3 & 27 & مطمئن \\
\hline 78.5 & 139 & مستسلم لقضاء الله \\
\hline$\% 100$ & 177 & المجموع \\
\hline
\end{tabular}

يتضح من الجدول رقم (4 -19) أن (139) من أفراد الدر اسة الذين أصيبوا أو أحد أفراد عائلاتهم بكورونا يمثلون ما نسـبته 78.5٪ من الذين أصـيبوا أو أحد أفر اد عائلاتهم بكورونا شـعور هم بعد الإصـابة مسـتســلم لقضاء الله، بينما (27) منهم يمثلون ما نسبته 15.3٪ من إجمالي أفراد الدر اسة من الذين أصيبوا أو أحد أفراد عائلاتهم بكورونا شعور هم بعد الإصابة الاطمئنان، و (11) منهم يمثلون 6.2٪ من إجمالي أفراد الدراسة من الهن الذين أصيبو ا أو أحد عائلاتهم بكورونا شعور هم بعد الإصابة بالخوف من الموت. 
المجلة الدولية لنشر البحوث والدراسات

International Journal of Research and Studies Publishing

ISSN: 2709-7064
المجلد الثالث - الإصدار الرابع والعشرون تأريخ الإصدار: 20 أكتوبر 2021م الاصدار الع المابد

20) هل غيّر وباء كورونا حياتك:

جدول رقم (20-4) توزيع أفراد الدراسة وفق متغير هل غيّر وباء كورونا حياتك

\begin{tabular}{|c|c|c|}
\hline النسبة \% & التكرار & هل غيّر وباء كورونا حياتك \\
\hline 2.0 & 10 & إلى الافضل مادياً \\
\hline 4.2 & 21 & إلى الأسو أ مادياً \\
\hline 26.4 & 132 & اقتربت من اله \\
\hline 26.2 & 131 & اقتربت من أهلي \\
\hline 7.4 & 37 & الأفضل مادياً ودينياً \\
\hline 1.6 & 8 & أقل مادياً ودينياً \\
\hline 32.2 & 161 & غير ذللك \\
\hline$\% 100$ & 500 & المجموع \\
\hline
\end{tabular}

يتضــح من الجدول رقم (4 -20) أن (161) من أفراد الدر اســة يمثلون ما نســبته 32.2\% غيّر وباء

كورونـا حياتهم لغير ذلك، بينما (132) يمثلون 26.4٪ من إجمالي أفراد الدراســـة غيّر وباء كورونا حياتهم بـالاقتر اب من الله، و (131) منهم يمثلون 26.2٪ من إجمـالي أفر اد الـدراســــة غيّر وبـاء كورونـا حيـاتهم بالاقتر اب من أهلهم، و (37) منهم يمثلون 7.4٪ من إجمالي أفر اد الدر اسة غيّر وباء كورونا حياتهم للأفضل

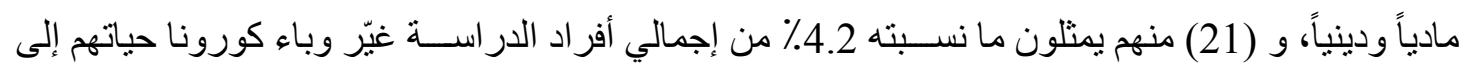
الأسـوء مادياً، و (10) منهم يمثلون ما نسـبته 2.0٪ من إجمالي أفر اد الدر اسـة غيّر وباء كورونا حياتهم إلى مئى الافضـل مادياً، و (8) منهم بمثلون ما نسـبته 1.6 1. من إجمالي أفر اد الدر اســة غيّر وباء كورونا حياتهم لأقل

مادياً ودينياً.

21) هل تعتقد أنك مأجور في هذه الجائحة:

جدول رقم (21-4) توزيع أفراد الدراسة وفق متغير هل تعتقد أنكك مأجور في هذه الجائحة

\begin{tabular}{|c|c|c|}
\hline النسبة \% & التكرار & هل تعتقد أنك مأجور في هذه الجائحة \\
\hline 51.2 & 256 & نعم \\
\hline 6.0 & 30 & لا علاقة للأجر في الجائحة \\
\hline 0.6 & 3 & مأجور لمساعدة الناس \\
\hline 0.6 & 3 & مأجور لمساعدة أهلي \\
\hline 8.6 & 43 & مأجور للالتز ام بالحظر \\
\hline 33.0 & 165 & مأجور على كل شيء \\
\hline$\% 100$ & 500 & المجموع \\
\hline
\end{tabular}


يتضـح من الجدول رقم (4 -21) أن (256) من أفراد الدر اسـة يمثلون ما نسبته 51.2\% يعتقدون أنهم مأجورين في هذه الجائحة، بينما (165) منهم يمثلون ما نســبته 33.0٪ من إجمالي أفر اد الدر اســـة يعتقدون أنهم مأجورين في هذه الجائحة على كل شيء، و (43) منهم بمثلون 8.6٪ من إجمالي أفر اد الدر اسة بعتقدون

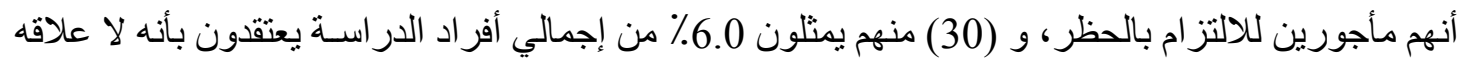

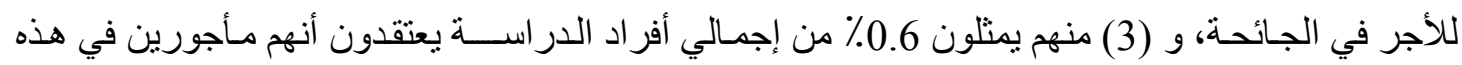
الجائحة لمسـاعدة الناس، و (3) منهم يمثلون 0.6٪ من إجمالي أفر اد الدر اسـة يعتقدون أنهم مأجورين في هذه الجائحة لمساعدة أهلهم. 22) هل زادت فترات قراعتك للقر آن: جدول رقم (22-4) توزيع أفراد الدراسة وفق متغير هل زادت فترات قراعتك للقرآن

\begin{tabular}{|c|c|c|}
\hline النسبة \% & الت التكر ار & هل ز ادت فتر ات قر اءتك للقر آن \\
\hline 35.8 & 179 & $y$ \\
\hline 64.2 & 321 & 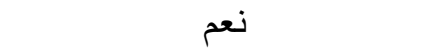 \\
\hline$\% 100$ & 500 & المجموع \\
\hline
\end{tabular}

يتضـح من الجدول رقم (422) أن (321) من أفر اد الدر اسـة يمثلون ما نسبته 64.2\% ز ادت فترات

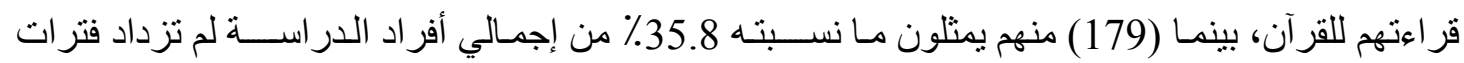
قر اءتهم للقران. 23) هل كنت تدعو الله بكشف الكربة: جدول رقم (23-4) توزيع أفراد الدراسة وفق متغير هل كنت تدعو الله بكثف الكربة

\begin{tabular}{|c|c|c|}
\hline النسبة \% & التكر ار & هل كنت تدعو الله بكثف الكربة \\
\hline 5.8 & 29 & $\bar{\gamma}$ \\
\hline 94.2 & 471 & نمع \\
\hline$\% 100$ & 500 & المجموع \\
\hline
\end{tabular}

يتضـح من الجدول رقم (4 -23) أن (471) من أفراد الدر اسـة يمثلون ما نسبته 94.2\% كانو ا يدعون

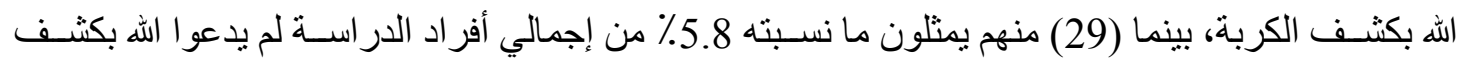
الكربة.

24) هل تعتقد أن وباء كورونا:

جدول رقم (24-4) توزيع أفراد الدراسة وفق متغير هل تعتقد أن وباء كورونا

\begin{tabular}{|c|c|c|}
\hline النسبة \% & التكر ار & هل تعتقد أن وباء كورونا \\
\hline 72.4 & 362 & ابتتلاء وتذكير من الله \\
\hline
\end{tabular}


المجلة الدولية لنشر البحوث والدراسات

International Journal of Research and Studies Publishing

ISSN: 2709-7064

\begin{tabular}{|c|c|c|}
\hline 16.8 & 84 & حدث بيئي \\
\hline 10.8 & 54 & عقاب من الله \\
\hline$\% 100$ & 500 & المجموع \\
\hline
\end{tabular}

يتضـح من الجدول رقم (424) أن (362) من أفر اد الدر اسـة يمثلون ما نسـبته 72.4\% يعتقدون أن

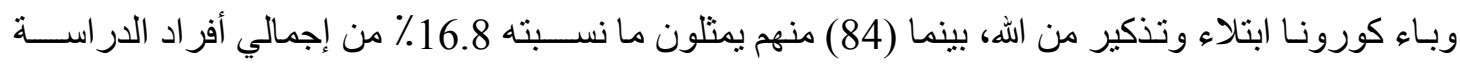
يعتقدون أن وبـاء كورونـا حدث بيئي، و (54) منهم يمتلون مـا نســبته 10.8٪ من إجمالي أفر اد الدراســـة بعتقدون أن وباء كورونا عقاب من الله.

25) هل تعرف كيف علمنا النبي صلى الله عليه وسلم التعامل مع الأوبئة: جدول رقم (4-25) توزيع أفراد الدراسة وفق متغير هل تعرف كيف علمنا النبي صلى الله عليه وسلم التعامل مع الأوبئة

\begin{tabular}{|c|c|c|}
\hline النسبة \% & التكر ار & هل تعرف كيف علمنا النبي صلى الله عليه وسلم التعامل \\
\hline 40.8 & 204 & $\bar{y}$ \\
\hline 59.2 & 296 & نعم \\
\hline$\% 100$ & 500 & المجموع \\
\hline
\end{tabular}

يتضـح من الجدول رقم (4 -25) أن (296) من أفر اد الدر اسـة يمثلون ما نسبته 59.2\% يعرفون كيف

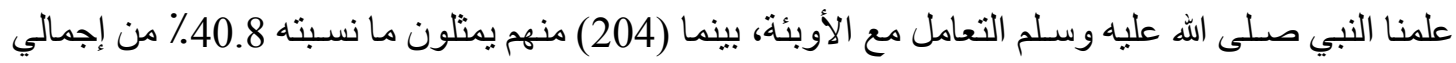
أفر اد الدر اسة لا يعرفون كيف علمنا النبي صلى الله عليه وسلم التعامل مع الأوبئة. 26) هل سمعت عن طاعون عمواس وكيف تعامل الصحابة معه: جدول رقم (4-26) توزيع أفراد الدراسة وفق متغير هل سمعت عن طاعون عمواس وكيف تعامل الصحابة

\begin{tabular}{|c|c|c|}
\hline \multicolumn{3}{|r|}{ معd } \\
\hline النسبة \% & التكرار & هل سمعت عن طاعون عمواس وكيف تعامل الصحابة \\
\hline 58.0 & 290 & $y$ \\
\hline 42.0 & 210 & نعم \\
\hline$\% 100$ & 500 & المجموع \\
\hline
\end{tabular}

يتضـح من الجدول رقم (4 -26) أن (290) من أفر اد الدر اسة يمثلون 58.0٪ لم يسمعوا عن طاعون عمو اس وكيف تعامل الصحابة معه، بينما (210) منهم يمثلون 42.0٪ من إجمالي أفر اد الدر اسة سمعو ا عن طاعون عمو اس وكيف تعامل الصحابة معه. 
27) إذا كانت الإجابة نعم فأين تعلمت عنه:

جدول رقم (4-27) توزيع أفراد الدراسة وفق متغير إذا كانت الإجابة نعم فأين تعلمت عنه

\begin{tabular}{|c|c|c|}
\hline النسبة \% & التكرار & إذا كاتت الإجابة نعم فأين تعلمت عنه \\
\hline 18.6 & 39 & 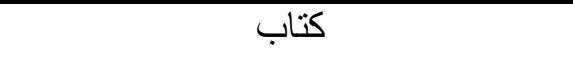 \\
\hline 42.4 & 89 & تو اصل اجتماعي \\
\hline 13.3 & 28 & محاضرة صوتية أو مرئية في احد القنو ات \\
\hline 25.7 & 54 & صديق او قريب \\
\hline$\% 100$ & 210 & المجموع - المجوع \\
\hline
\end{tabular}

يتضـح من الجدول رقم (4 -27) أن (89) من أفر اد الدر اسـة من الذين سـمعوا عن طاعون عمواس

وكيف تعامل الصــحابة معه يمثلون ما نسـبته 42.4\% من الذين ســمعو ا عن طاعون عمو اس وكيف تعامل

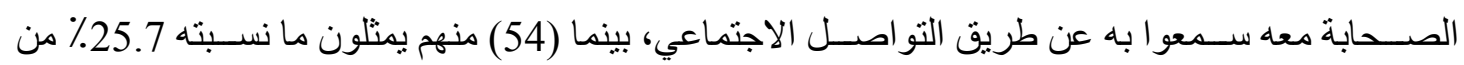

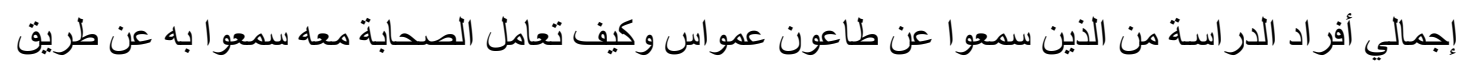

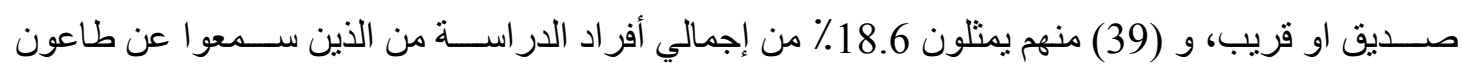

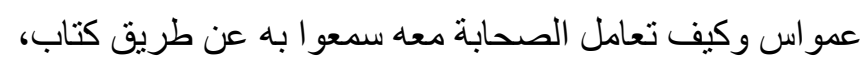

و (28) منهم يمثلون 13.3\% من إجمالي أفر اد الدر اسـة من الذين سـعو ا عن طاعون عمو اس وكيف تعامل الصحابة معه سمعو ا به عن طريق محاضرة صوتية أو مرئية في أحد القنوات.

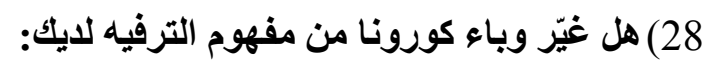

جدول رقم (28-4) توزيع أفراد الدراسة وفق متغير هل غيّر وباء كورونا من مفهوم الترفيه لايك

\begin{tabular}{|c|c|c|}
\hline النسبة \% & 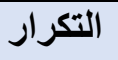 & هل غيّر وباء كورونا من مفهوم الترفيه لديك \\
\hline 18.4 & 92 & $\bar{y}$ \\
\hline 22.0 & 110 & 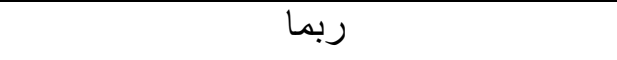 \\
\hline 59.6 & 298 & 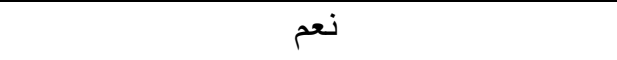 \\
\hline$\% 100$ & 500 & المجموع \\
\hline
\end{tabular}

يتضـــح من الجدول رقم (4 -28) أن (298) من أفراد الدر اســة يمثلون ما نســبته 59.6\% غيّر وباء كورونا من مفهومهم للترفيه، بينما (110) منهم يمنلون ما نسبته 22.0٪ من إجمالي أفر اد الدر اسة ربما غيّر وباء كورونا من مفهومهم للترفيه، و (92) منهم يمثلون ما نسـبته 18.4\% من إجمالي أفر اد الدر اســة لم يغيّر وباء كورونا من مفهومهم للترفيه. 29) هل تشعر أنه كان من المهم غلق المساجد حتى لا تنتشر العدوى: 
جدول رقم (4-29) توزيع أفراد الدراسة وفق متغير هل تثعر أنه كان من المهم غلق المساجد حتى لا تنتثر العدوى

\begin{tabular}{|c|c|c|}
\hline النسبة \% & التكر ار & هل تشعر أنه كان من المهم غلق المساجد حتى لا تنتشر \\
\hline 9.6 & 48 & $\bar{y}$ \\
\hline 90.4 & 452 & نعم \\
\hline$\% 100$ & 500 & المجموع \\
\hline
\end{tabular}

يتضـح من الجدول رقم (4 -29) أن (452) من أفر اد الدر اسـة يمثلون ما نسبته 90.4\% يشـعرون أنه

كان من المهم غلق المسـاجد حتى لا نتتشر العدوى، بينما (48) منهم يمثلون ما نسبته 9.6\% من إجمالي أفر اد الدراسة لا يشعرون أنه كان من المهم غلق المساجد حنى لا تنتشر العدوى.

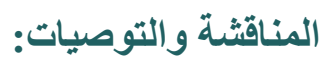

- أظهرت النسب وجود و عي ديني فوق المتوسط وعلاقة مطردة مع التعلق بالله و التوكل عليه لكثف الضر، ونسبة 100\% يعيش مع أهله وذويه مما يدل على قوة الترابط الأسري في المجتمع، مع نسبة متوسطة من التوتر والقليل من كان يشعر بالخوف، ونسبة العنف كذلك كانت أقل من النصف، أعلاها

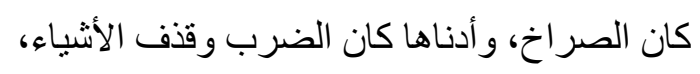
و أبرز عامل لذلك كان للملل و عدم وجود تسلية وقت الحظر، و ومقارنة بالدر اسة التي أجريت في بريطانيا، في أواخر مارس الماضي من عام 2020، لدى أكاديمية العلوم الطبية في المملكة المتحدة تبين أن هنالك زيادة معدلات القلق والتوتر أثناء الوباء، و أعداد المكتبئين و المُقدمين على الانتحار ، و في عام 2003، في ظل انتشار وباء سارس، زاد الثعور بعدم الأمان المالي و الفقر، وز ادت معدلات الانتحار بين الثباب و من تجاوزوا 65، ارتفاعا بنسبة 30\%، وذللك ارتباطا بالوحدة و اليأس و الحاجة للبحث عن لقمة العيش، ( بروكسي، 2020)، و هذا يختلف عن حال الكبار في السن في مجتمعنا، فالكبير في السن في مجتمعنا غالبا: مع عائلته تقوم بخدمته، ور عاية شؤونه. - كان أكثر من النصف بقليل من يعرف الأحكام المفصلة لمو اجهة الوباء، و أغلب من سمع بأحكامه كان عن طريق وسائل التواصل الاجتماعي، وهذا بدل على أن هناك حاجة لدى العلماء في تكتيف تعليم الأحكام الثر عية لمو اجهة الوباء عبر وسائل الإعلام المختلفة. - - نسبة قليلة من الأشخاص من بعتقد بعدم علاقة الأجر بالصبر على الجائحة، و أنه لا علاقة لله بحدوث

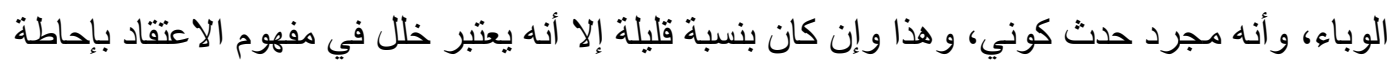
الله تعالى و التوكل عليه وينبغي مر اعاته و عدم تجاهله عند التوجيه. 
- تفاوتت نسب النفع و الضرر نتيجة الجائحة بشكل منقارب نسبيا، وكان أعلى أثر اللنفع هو النفع الاجتماعي بنسبة 41 \%، فيما توزعت النسب على الباقي، ولذا ينبغي تعزيز الجانب الإيجابي للجائحة واعتبار ها

$$
\begin{aligned}
& \text { نفعا أكثر من كونها ضررا. } \\
& \text { توصيات الدراسة: }
\end{aligned}
$$

•الحاجة لتعليم الناس الأحكام الفقهية المتعلقة بالوباء، وربطها بالوسائل المعاصرة، بشكل مفصل ولا

$$
\text { يكتفى بالو عي العام خاصة فيما يتعلق بالأحكام الضرورية كالوباء. }
$$

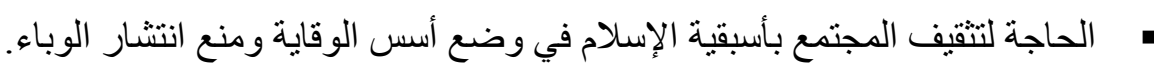

• ربط وسائل التعامل مع الوباء بالعلم الثرعي حتى يكون أجدى نفعا وأبلغ في التقبد و الالتز ام.

• تعليم الأسرة خاصة الأطفال الأذكار و التوكل و التفاؤل وحسن الظن به، مع بذل أسباب الوقاية.

$$
\text { • توعية الناس بحكم العنف في الإسلام وطرق مو اجهنه. }
$$

التو عية بأحكام الترفيه، و على المسؤولين تفعيل الأنشطة الترفيهية المباحة مع التزام التباعد.

$$
\text { التوعية بعدم المبالغة في الخوف أو اللامبالاة خلال انتشار وباء كورونا. }
$$

• إجر اء تقويم مستمر لواقع المجتمع وقت الوباء، و إيجاد الحلول الثرعية المناسبة.

مقترحات للار اسات المستقبلية:

• إجر اء در اسة مماثلة على مستوى الدول العربية والإسلامية.

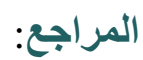

ابن الحجاج. مسلم. (د ت). صحيح مسلم. تأليف دسلم بن الحجاج، صحيح مسلم (ت: محدد عبد الباقي) .

$$
\text { بيروت: دار إحياء التراث العربي. }
$$

ابن حنبل. أحمد (1421). مسند الإمام أحمد.(ط1). (ت: شعيب اللأرناؤوط) بيروت: مؤسسة الرسالة. ابن منظور. أبو الفضل (1414). لسان العرب ( ط3). بيروت: دارصادر. أبويعلى. أحمد (1404). مسند أبو يعلى (ط1). (ت:حسين أسد) دمشق: دار المأمون. البخاري. محمد (1422). صحيح البخاري (ط2). (ت: محمد الناصر ) بيروت: دار طوق النجاة. التويجري. محمد (1431). مختصر الفقه، (ط1). السعودية: دار أصداء المجتمع. التويجري. محمد (1430). موسوعة الفقه الإسلامي (ط1). الأردن: بيت الأفكار. الزبيدي. مرتضى (1408). تخريج علوم الدين (ط1). الرياض: دار العاصمة. البيهقي. أبوبكر (1424). سنن البيهقي الكبرى ( ط3). (ت: محمد العطا) بيروت: دار الكتب العلمية. الحاكم. أبو عبداله ( 1411 ). المستدرك على الصحيحين ( ط1). بيروت: دار الكتب العلمية. الطبر اني. سليمان (1405). المعجم الصغير ( ط1). (ت: محمد شكور ) بيروت: دار عمار. العساف، صالح أحمد. (2012). المدخل إلى البحث في العلوم السلوكية. ط2. الرياض: دار الزهر اء. 


$$
\begin{aligned}
& \text { الفيومي. أحمد (د ت). المصباح المنير في غريب الثرح الكبير ( د ط). بيروت: المكتبة العلمية. } \\
& \text { المباركفوري. عبدالرحمن (د ت). تحفة الأحوذي (د ط). بيروت: دار الكتب العلمية. } \\
& \text { المجمع الفقهي. (12-711، 1412). الدورة السابعة. مجلة المجمع الفقهي. } \\
& \text { النعيمي. راشد (14 سبتمبر 2020). دول الخليج الأقل تأثرا بكورونا عالميا، ماكي }
\end{aligned}
$$

https://www.alkhaleej.ae/

أنس. مالك (د ت). الموطأ على رواية محمد الثيباني (ط2). (ت: عبدالو هاب عبداللطيف، المحرر) بيروت:

$$
\text { المكتبة العلمية . }
$$

bbc: بروكسي. فيلييا (16- 4، 2020). قيروس كورونا: علماء يحذرون https://www.bbc.com/arabic/science-and-tech-52314172 خوجه. عبدالحفيظ (10 4، 2020). كيف نحصن صحتنا النفسية في زمن كورونا. صحيفة الأوسط: /https://aawsat.com/home/article/2213546

رويترز. (14 5، 2020). خبر اء يحذرون أزمة صحة نفسية عالمية بسبب كورونا. صحيفة الاقتصادية: https://www.aleqt.com/2020/05/14/article_1827486.html صلاح. خالد (28 12، 2020). كبار العلماء بالأزهر : الثرع يلزم بالإجر ائات الاحترازية. موقع اليوم https://www.youm7.com/story/2020/12/27/5131418 السابع فريق دقائق. (11 3، 2020). الدين في زمن كورونا. مجلة دقائق: /https://daqaeq.net WHO: منظمة الصحة العالمية. (13- 3، 2018). الصحة النفسية. https://www.who.int/ar/news/. منظمة الصحة العالمية. (11- 6، 2019). الصحة النفسية في حالات الطوارئ . https://www.who.int/ar/news/.

$$
\text { منظمة الصحة العالمية. (2021). عدوى فيروس كورونا. }
$$

/https://www.who.int/csr/disease/coronavirus_infections/ar Cambridge University. (2021). Learner's Dictionary \& Thesaurus. Cambridge: Cambridge University Press.

\section{Doi: doi.org/10.52133/ijrsp.v3.24.1}

